\title{
EKSISTENSI PONDOK PESANTREN DI TENGAH KEMODERNAN PESANTREN
}

\author{
Khairurrijal \\ Pondok Pesantren Musthafawiyah Purba Baru Jl. Medan-Padang Purba Baru, Kec. \\ Panyabungan Selatan Kab. Mandailing Natal Sumatera Utara (0636) 20575/3221747- \\ ponpesmusthafawiyah@gmail.com- Pos Kayulaut 22952 \\ e-mail: khairurrijal1991@gmail.com
}

\begin{abstract}
The issue of this research was to understanding the tradition and education model stiil exists Musthafawiyah Islamic Boarding School since exists to this nowadays. The purpose of this study is to reveal why Musthafawiyah Islamic Boarding School stiil exists in the modernity Islamic Boarding School and consistenly in existenly tradition and education model. The research is using qualitative method whit type case study. The approach in the research is using historis-fhenomenologis. Techniques in collecting data is using observation dan interview. Sources of data in the research consist of the leader, teahers, students, and workers Musthafawiyah Islamic Boarding School. Data analysis techniques use data reduction, data presentation and conclusion. The results showed that existence Musthafawiyah Islamic Boarding School because five factor, (1) Musthafawiyah Islamic Boarding School management; desirability structural Musthafawiyah Islamic Boarding School for continue of tradition the construct Syekh Musthafa Husein, construct the thought of structural Musthafawiyah Islamic Boarding School to relevant education model of Musthafawiyah in midst modernisme education, (2) the traditional factor with to defend the yellow book as hand-grip the student at traditional Muslim school, (3) the economic factor;life expense and education which a relative cheap, (4) the sincerity teachers as dedication to Musthafawiyah Islamic Boarding School without view a give the retainer, and (5) the subservience and loyality the student at traditional Muslim school as implementation from a value at to teach.
\end{abstract}

Keywords: Tradition, Education Model, Teaching Method

\section{PENDAHULUAN}

Pondok pesantren sebagai lembaga pendidikan Islam telah lama memainkan peran yang strategis di tengah-tengah kehidupan masyarakat dan bangsa Indonesia. Sejak mula pesantren merupakan salah satu model pendidikan yang sudah lama mengakar dalam kehidupan masyarakat Indonesia. Bahkan, memiliki sifat dan karakteristiknya tersendiri yang mampu menyesuaikan diri memenuhi tuntutan masyarakat (Taruna, 2013: 113-114). Pasca kemerdekaan, pesantren berhadapan dengan arus modernisme. Akibatnya, 
terjadi perubahan format, bentuk, orientasi, dan metode pendidikan dalam dunia pesantren. Namun demikian, perubahan tersebut tidak merubah visi, misi, dan orientasi pesantren. Dapat dikatakan, perubahan tersebut hanya pada sisi luarnya saja, sementara pada sisi dalam, yaitu ruh, semangat, pemahaman keagamaan, nilai-nilai, tradisi, dan ideologi pesantren tetap dipertahankan (Ngatawi, 2006: 5-6). Keberadaan pesantren sebagai lembaga pendidikan Islam yang tetap survive dengan peningkatan dari segi jumlah santri/santriwati sebagai bukti kongkrit bahwa pesantren masih diminati di tengah modernisasi lembaga pendidikan, meskipun banyak muncul lembaga-lembaga pendidikan umum yang lebih maju. Perubahan model pendidikan yang dikelola oleh setiap pesantren untuk mengadopsi keinginan masyarakat sebagai pengguna layanan pendidikan pesantren. Pengadopsian model tersebut bertujuan untuk mempertahankan eksistensi pesantren dalam fungsinya sebagai lembaga pendidikan dalam menghadapi tantangan kemajuan ilmu pengetahuan dan teknologi yang semakin cepat akibat tuntutan perubahan zaman. Tantangan dunia pesantren saat ini semakin terasa. Hal ini disebabkan banyak fenomena kontemporer yang menuntut pesantren harus lebih terbuka. Pesatnya perkembangan sains dan teknologi yang mengantarkan pada fenomenafenomena globalisasi, serta kompleksitas persoalan-persoalan kehidupan telah menjadi ikon tersendiri yang perlu direspon secara kreatif dan produktif oleh pesantren. Untuk merespon semua tantangan tersebut, pesantren memerlukan paradigma yang selama ini telah lama dianut oleh dunia pesantren yaitu "al-Muhafdzah ala al-Qadim ash-Shalih wa al-Akhdz bi al-Jadid al-Aslah" (Bina Pesantren, 2006: 46-47). Dalam menghadapi tantangan tersebut, setidaknya pesantren harus mampu bertahan hidup (survival) dalam menghadapi dan merespon tantangan-tantangan globalisasi yang dapat menggangu eksistensi pondok pesantren disebabkan kemajuan dan perkembangan ilmu pengetahuan dan teknologi. Pada akhir-akhir ini, sesuai dengan perkembangan zaman, ilmu pengetahuan, dan teknologi, maka keberadaan pondok pesantren tradisional sudah jarang ditemukan. Salah satu pondok pesantren yang masih eksis untuk mempertahankan tradisi dan model pendidikan tradisionalnya, namun tetap menyesuaikan terhadap perkembangan zaman dan ilmu pengetahuan tanpa harus menghilangkan identitasnya sebagai pondok pesantren, yaitu pondok pesantren Mushtafawiah Purba Baru. 


\section{KAJIAN TEORITIS}

Membahas tentang pesantren tidak bisa lepas dari tradisi dan model pendidikan yang dianut oleh setiap pesantren. Keberadaan tradisi dan model pendidikan menjadikan satu pesantren berbeda dengan pesantren lainnya sebagai bentuk karakteristik dan keunikan pesantren. Pesantren yang ada di Sumatera Utara memiliki kesamaan dari aspek kitab kuning, pondok, masjid, cara berpakaian santri, dan kyai. Namun, dari aspek tradisi terdapat perbedaan. Ini merupakan keunikan pesantren yang tidak adanya terdapat keseragaman, meskipun ada kesamaan dan kemiripan.

Tradisi merupakan suatu kebiasaan yang telah berlangsung sejak lama kemudian dilanjutkan oleh generasi penerus. Istilah tradisi dalam Kamus Besar Bahasa Indonesia Kontemporer disebutkan bahwa tradisi adalah adat kebiasaan turuntemurun yang masih dijalankan dalam lingkungan masyarakat (Salim, 1991: 1636). Dalam konteks ini, tradisi yang dimaksud adalah cara dan sikap yang selalu dipegang teguh oleh pimpinan dan seluruh pihak pesantren Musthafawiyah untuk melanjutkan apa yang telah dibina oleh Syekh Musthafa Husein Nasution.
Menurut Kamus Besar Bahasa Indonesia, klasikal adalah bersamasama di dalam kelas (Depdiknas, 1994: 507). Model pendidikan klasikal di pesantren merupakan upaya perubahan dan kemajuan untuk menghadapi tantangan pendidikan di Indonesia. Dalam model ini, pesantren menyelenggarakan pendidikan keagamaan dalam bentuk madrasah dan mengajarkan ilmu-ilmu umum meskipun tidak menerapkan kurikulum nasional (Arief, 2002: 197). Dalam hal ini, model klasikal yang dimaksud yaitu kegiatan belajarmengajar secara bersama-sama yang dilaksanakan dalam kelas yang terdiri dari santri 50-60 orang yang dilakukan oleh seorang guru.

Model Non-Klasikal adalah kegiatan pembelajaran yang tidak menerapkan sistem kelas dengan menggunakan metode wetonan, bandongan, serta hafalan yang disampaikan pada pengajian kitab-kitab klasik yang materinya hanya ilmu-ilmu saja (Daulay, 2009: 31). Dalam hal ini, pembelajaran yang dilaksanakan tidak menggunakan sistem kelas, kenaikan kelas, tidak ada evaluasi, dan tidak ada absensi. Model ini lebih akrab dengan sebutan "pengajian" yang diadakah oleh sejumlah santri yang terdiri dari satu tingkatan, maupun dari berbagai tingkatan dengan kitab yang sama. 
Model Single Sex Education. Yaitu suatu model lembaga pendidikan dengan proses pembelajaran terpisah antara siswa laki-laki dan perempuan dengan memisahkan ruang belajarnya (Susanne, 2013: 6). Prinsip ini sesuatu yang ideal karena anak yang berusia muharriqah (masa remaja) tidak memiliki ketenangan jiwa dan dikhawatirkan akan timbul hal-hal yang dapat merusak moral (Assegaf, 2013: 72).

Metode Bandongan. Yaitu suatu pengajaran kitab yang dilakukan dengan membacakan salah satu kitab di depan santri yang juga memegang kitab yang sama dan memperhatikan kitab yang sama juga, kemudian santri mencatat apa yang dibaca oleh guru pada kitab yang dipegang oleh santri. Tidak ada evaluasi dalam metode ini, karena santri hanya mendengarkan dan mencatat apa yang dibaca oleh guru (Tatang, 2012: 167). Secara etimologi bandongan diartikan dengan pengajaran dalam bentuk kelas (pada sekolah agama). Secara terminologi, sebagaimana yang dikemukakan oleh Imran Arifin dalam bukunya "Kepemimpinan Kyai" metode bandongan adalah kyai membaca suatu kitab dalam waktu tertentu dan santri membawa kitab yang sama, kemudian santri mendengarkan tentang bacaan kyai tersebut (Arief, 2002: 153-154).
Metode Sorogan. Yaitu sebuah sistem belajar para santri menghadap guru satu persatu untuk membaca dan menguraikan isi kitab di hadapan seorang guru (Utomo, 1997:83). sorogan juga diartikan belajar secara individu dimana seorang santri menghadap seorang guru sehingga terjadi interaksi antara keduanya (Mastuhu, 1994: 61). Sistem pembelajaran dibuat agar santri memahami struktur kalimat dan artinya. Maka inti dari metode ini berlangsungnya proses pembelajaran secara face to face antara santri dengan guru (Arief, 2002: 151).

Metode Tanya Jawab. Yaitu penyampaian pelajaran dengan cara guru mengajukan pertanyaan dan murid menjawab. Dalam pengertian lain dapat juga dikatakan cara penyampaian materi pelajaran dalam bentuk pertanyaan agar dijawab oleh murid maupun sebaliknya (Zuhairini, 1983: 83). Dalam konteks ini, guru bertanya kepada santri maupun sebaliknya terkait dengan materi yang disampaikan, kemudian menilai proses tanya jawab yang berlangsung dan diakhiri dengan tindak lanjut dari guru.

Metode Hukuman. Dalam Kamus Besar Bahasa Indonesia, diartikan dengan siksa yang diberikan karena telah melanggar undangundang dan sebagainya; hasil atau akibat menghukum (Depdikbud, 1994: 
360). Jika dikaitkan dengan pendidikan, maka hukuman berarti; alat pendidikan preventif dan represif yang tidak menyenangkan; imbalan dari perbuatan yang tidak baik dari peserta didik (Arief, 2002:130-131).

\section{METODE PENELITIAN}

Jenis penelitian yang digunakan adalah field research (penelitian lapangan) dengan menggunakan metode deskriftif-kualitatif. Pendekatan yang digunakan adalah historisfhenomenologis. Hal ini dikarenakan keberadaan pesantren Musthafawiyah tidak bisa dilepaskan dari akar sejarah yang mencakup objek, orang, situasi, dan peristiwa di masa lalu. Fhenomenologis berupaya untuk memahami dengan memberikan interpretasi terhadap nilai, makna simbol-simbol, tradisi dan model pendidikan pesantren Musthafawiyah. Instrumen utama dalam penelitian ini adalah peneliti sendiri yang dibantu oleh field-notes dan camera digital. Sumber data dalam penelitian ini yaitu berbagai peristiwa, aktivitas, dan situasi yang terjadi dilingkungan pesantren Musthafawiyah. Teknik pengumpulan data yang digunakan observasi dan wawancara dengan santri, kyai, dan orang tua santri. Ada dua jenis wawancara yang dugunakan dalam penelitian ini, yaitu terstruktur dan semi terstruktur. Untuk menguji keabsahan data yang didapatkan, peneliti menggunakan teknik perpanjangan lapangan, triangulasi data dan sumber, dan member-check. Dalam melakukan analisis data, penulis menggunakan reduksi data, penyajian data, dan penarikan kesimpulan.

\section{HASIL PENELITIAN DAN PEMBAHASAN}

\section{Hasil Penelitian}

\section{Tradisi}

Sebagai lembaga pendidikan Islam indegeneous Indonesia, pesantren memiliki karakteristik tersendiri yang membedakan dari pesantren lain. Hal inilah yang menjadikan pesantren sebagai kultur yang unik. Perbedaan tersebut dapat dilihat dari tradisitradisi sebuah pesantren. Adapun tradisi pesantren Musthafawiyah yang masih dipertahankan hingga saat ini, sebagai berikut:

1. Cara berpakaian. Penggunaan serban pada awalnya khusus untuk santri kelas VII sebagai pembeda dengan santri tingkatan bawah (kelas I-VI), meskipun tidak ada larangan bagi santri kelas I-VI untuk memakainya. Namun mereka tidak mau memakainya karena merasa belum pantas untuk menggunakannya. Akan tetapi, seiring dengan perubahan sosial dalam kehidupan santri, maka saat ini serban bukan lagi jadi pembeda, 
melainkan dengan penggunaan jas. Maka jika ada santri yang memakai jas ketika pergi belajar, maka sudah dapat dipastikan bahwa santri tersebut kelas VII.

2. Kitab kuning. Pesantren selalu diidentik dengan kitab kuning. Karena kitab kuning merupakan kitab pegangan santri dan kyai. Begitu juga dengan pesantren Musthfawiyah yang masih mempertahankan kitab kuning sebagai kajian utama. Untuk meningkatkan ketekunan santri dalam memahami kitab kuning, pesantren Musthafawiyah mengadakan MQK (Musabaqah Qiraat al-Kitab) pada tiap semester. Keteguhan pesantren untuk mempertahankan kitab kuning di tengah banyaknya bukubuku terjemahan yang muncul dikarenakan untuk melanjutkan tradisi yang telah lama berlangsung di pesantren Musthafawiyah, juga karena kitab terjemahan tersebut terjemahan bebas. Namun yang paling urgen dipertahankan kitab kuning tersebut untuk mengimplementasikan ilmu alat yang dipelajari, yaitu ilmu nahwu (gramatika), saraf (morfologi), dan balaghah (stilistik).

Sebagaimana yang dikemukakan oleh Azyumardi Azra bahwa istilah kitab kuning tidak terlepas dari warna dan isi kitab tersebut. Hal ini bisa dilihat kebanyakan warna kertas kitab tersebut berwarna kuning dengan menggunakan teks Arab yang tidak memiliki harakat dengan format khusus (Azra, 2012: 51). Namun, akibat kemajuan zaman dan ilmu pengetahuan, maka ada dijumpai sebagian warna kitab tersebut berwarna putih, tetapi tetap disebut kitab kuning dan bukan kitab putih.

3. Menghafal malam. Kegiatan ini untuk mengawasi berbagai aktivitas santri pada malam hari dilingkungan komplek tempat tinggal santri (banjar). Dalam kegiatan ini, para guru dibantu oleh Dewan Pelajar (DEPEL) yang ditunjuk oleh pesantren. Jaga malam ini dimulai setelah Isya (20.30 WIB) dan berakhir pada jam 22.30 WIB. Para guru dan DEPEL akan memasuki banjar tempat tinggal santri. Jika ditemukan santri yang tidak menghafal, tidur, atau main-main, maka akan ditegur secara langsung dan disuruh menghafal. Tidak diketahui secara pasti kapan jaga malam ini mulai diterapkan di pesantren, namun kegiatan sebagai bentuk pengawasan dari pesantren untuk meningkatkan belajar santri pada malam hari di tengah perkembangan media yang dapat melalaikan seorang santri dari tugas utamanya, yaitu menuntut ilmu. 
4. Tinggal di pondok. Pada awalnya belum ada pondok di lingkungan pesantren Musthafawiyah, namun dengan bertambahnya jumlah santri yang berdatangan dari berbagai daerah, maka santri tersebut mendirikan pondoknya masing sebagai tempat tinggal. Pada saat ini keberadaan pondokpondok tersebut berjejer dikirikanan jalan raya sepanjang $1 \mathrm{Km}$. Bercorak-ragam bentuk pondok tersebut yang dibuat oleh santri itu sendiri ada yang terbuat dari kayu dan bambu. Tidak diketahui secara pasti kapan pondok-pondok tersebut ada di pesantren Musthafawiyah, namun jika dilihat dokumentasi milik pesantren, bahwa pada tahun 1916 pondokpondok tersebut sudah ada ketika itu jumlah santri hanya 60 orang, mulai sejak itulah jumlah pondok tersebut terus bertambah hingga mencapai 1.500 unit, bahkan mungkin lebih.

5. Mudzakarah. Metode mudzakarah ialah suatu cara yang diterapkan dalam menyampaikan bahan pelajaran dengan mengadakan suatu pertemuan secara khusus untuk membahas masalah-masalah keagamaan (Arief, 2002: 157). Kegiatan mudzakarah yang dilaksanakan di pesantren Musthafawiyah sama dengan pengertian mudzakarah dalam pengertian yang dikemukan oleh para ahli, yaitu suatu forum diskusi tentang suatu topik tertentu untuk memecahkan masalahmasalah keagamaan. Kegiatan ini melibatkan guru dengan guru, maupun guru dengan santri. Namun, seiring dengan perkembangan dan perubahan zaman, istilah mudzakarah ini mulai mengalami perkembangan. Pada saat ini mudzakarah hampir dilaksanakan antara santri dengan santri di setiap banjar maupun persatuan santri yang ada di lingkungan pesantren Musthafawiyah. Dalam kegiatan ini santri senior yang kompoten dalam bidang tertentu, ditunjuk untuk mengajar dan membimbing santri junior, tanpa ada fee dari santri maupun dari persatuan untuk gaji santri yang mengajar dalam kegiatan tersebut. Kegiatan ini diadakan di luar jam proses belajarmengajar di lokal, biasanya dilaksanakan pagi dan malam hari.

6. Mengajar sepanjang hayat. Para guru yang mengajar di pesantren Musthafawiyah tidak mengenal istilah pensiun mulai sejak berdiri hingga saat ini. Prinsip ini tentunya sesuai dengan ajaran Islam bahwa tidak ada batas usia untuk mengajar dan belajar. Hanya ada dua hal yang menyebabkan guru tersebut berhenti mengajar di pesantren Musthafawiyah, yaitu 
karena faktor usia lanjut karena kendala kesehatan yang bisa memberikan kesulitan dan faktor kematian.

7. Libur hari Selasa. Pemilihan hari Selasa sebagai hari libur tidak terlepas dengan kondisi sosial Masyarakat desa Purba Baru bahwa pada saat itu pasar terdekat berada di Kayulaut. Maka pimpinan pesantren menetapkan hari Selasa sebagai hari libur untuk memberikan kesempatan pada santri berbelanja ke pasar untuk membeli kebutuhan harian. Perubahan sosial tidak mampu merubah tradisi hari libur tersebut, meskipun pada saat ini telah banyak warung yang menyediakan kebutuhan harian para santri. Namun, hari Selasa masih ditetapkan sebagai hari libur dan tidak akan diganti, meskipun kondisi sosial telah megalami perubahan.

8. Berorganisasi. Tradisi ini dimulai dari Syekh Musthafa Husein selaku pendiri pertama pesantren Musthafawiyah menjabat sebagai ketua Syarikat Islam Cabang Tanobato, hingga beliau mendirikan NU ketika NU sebagai lembaga pendidikan dan dakwah. Pada akhirnya, ketika NU menarik diri dari Masyumi pada tahun 1952, beliau terpilih sebagai anggota Syuriah NU pusat. Tradisi ini terus berlanjut sampai saat ini, bahkan ketika harlah NU ke-92 Sumatera Utara, ponpes Musthafawiyah terpilih sebagai tuan rumah.

\section{MODEL PENDIDIKAN}

Dalam melaksanakan proses pembelajaran ada tiga model pendidikan yang diterapkan di pesantren Musthfawiyah, yaitu:

1. Model Klasikal. Menurut Kamus Besar Bahasa Indonesia, klasikal adalah bersama-sama di dalam kelas (Depdiknas, 1991: 507). Dalam pelaksanaan model ini kegiatan belajar-mengajar dilaksanakan dalam kelas yang terdiri dari santri 50-60 orang yang setingkat. Kegiatan ini dilaksanakan pada waktu yang telah ditentukan oleh pihak pesantren yang harus diikuti oleh semua santri/santriwati.

2. Model Nonklasikal. Jenjang pendidikan dalam pesantren tidak dibatasi seperti dalam lembagalembaga pendidikan yang memakai model klasikal.Umumnya, kenaikan tingkat seorang santri ditandai dengan tamat dan bergantinya kitab yang dipelajari (Nizar, 2011: 288). Kegiatan ini hanya diadakan di luar jam pelajaran sebagai bentuk pelajaran tambahan. Ini dilaksanakan karena tidak semua kitab yang diajarkan di pesantren Musthafawiyah bisa diajarkan dilokal. Oleh karena itu, diadakan 
pelajaran tambahan (pengajian) diluar jam pelajaran lokal. Kegiatan ini dilaksanakan pada pagi hari sebelum jam belajar yang ditetapkan. Guru yang mengajar dalam kegiatan ini ditunjuk oleh pihak pesantren tanpa ada tambahan honor yang diberikan. Pengajaran ini hanya murni atas dasar kemauan dan keihklasan guru yang bersangkutan.

3. Model Single Sex Education. Yaitu model lembaga pendidikan dengan proses pembelajarannya terpisah antara siswa laki-laki dan perempuan dengan memisahkan ruang belajarnya (Susanne, 2013: 6). Hal ini sesuai dengan pendapat alQabisi, seharusnya perempuan dan laki-laki harus dipisahkan ruang belajarnya. Sebab bila dicampurkan akan dapat menimbulkan hal yang tidak baik, karena anak yang berusia muharrigah (masa remaja) tidak memiliki ketenangan jiwa dan dikhawatirkan akan timbul hal-hal yang dapat merusak moralnya (Assegaf, 2013: 72).

Dalam hal ini, santri dan santriwati dipisahkan, sehingga dalam satu lokal tersebut semuanya terdiri dari santri atau santriwati saja. Pemisahan ini bertujuan untuk menjaga kondisi lokal agar tetap kondusif, sehingga akhlak santri terhadap lawan jenis tetap terpelihara dengan baik. Selain itu, guru perempuan tidak diizinkan mengajar ke lokal santri, namun guru laki-laki diizinkan mengajar ke lokal santriwati, akan tetapi guru yang diizinkan hanyalah guru yang memiliki jiwa kebapak-an yang mampu menjaga sikap dan ucapannya terhadap santriwati. Tidak ada unsur diskriminatif dalam pemisahan ini, melainkan hanya untuk mempertahankan tradisi yang telah bertahan sejak lama. Selain itu, pemisahan ini juga dapat memberikan kemudahan kepada guru dalam mengajar dan mengelola kelas, sehingga proses pembelajaran tetap kondusif.

\section{Metode Pengajaran}

Pemilihan metode merupakan sesuatu yang penting dan perlu diperhatikan dalam proses belajarmengajar. Sebab, keberhasilan dan ketercapaian tujuan pengajaran sangat bergantung pada metode yang diterapkan. Maka tidaklah berlebihan apa yang pernah disebut ahli pendidikan bahwa metode lebih penting dari materi. Maka dalam proses belajar-mengajar, terutama dalam mengajarkan kitab kuning ada beberapa metode yang diterapkan. Adapun metode tersebut sebagai berikut:

1. Metode Sorogan. Sorogan artinya belajar secara individu di mana seorang santri berhadapan dengan seorang guru. Pelaksanaan metode 
sorogan ini biasanya diadakan ketika hendak memulai pelajaran baru. Guru menyuruh santri tertentu untuk membaca dan menterjemahkan kitab kuning yang dipelajari sebelumnya, sehingga guru mengetahui apakah santri tersebut ada memahami dan mengulang materi yang diajarkan atau tidak. Selain itu, pelaksanaan metode ini diadakan pada ujian semester satu, karena ujian dilaksanakan dengan bentuk lisan. Metode ini diterapan pada santri tingkatan menengah dan atas (kelas III-VII).

Maka dalam hal ini Maka dalam hal ini, metode sorogan merupakan metode yang efektif untuk meningkatkan pengetahuan dan pemahaman santri terhadap kitab kuning. Sebab, dengan metode ini, seorang guru dapat mengetahui dan mengukur tingkat penguasaan dan pemahaman santri terhadap kitab kuning. Dalam konteks pendidikan sekarang, metode ini sebagai bentuk implementasi dari pendekatan student center approach (pendekatan yang berpusat pada siswa), karena dalam metode ini, seorang guru hanya mendengarkan bacaan dari santri. Namun penerapan metode ini membutuhkan waktu yang lama, sehingga para guru akan mengalami kesulitan dengan waktu bila menerapkan metode ini dalam setiap proses belajar-mengajar. Tentu, setiap keunggulan suatu metode, pasti ada kelemahannya. Jelasnya, bahwa metode ini efektif, namun tidak efisien.

2. Metode Bandongan. Pelaksanaan metode ini diadakan pada kegiatan belajar-mengajar dalam kelas yang terdiri dari 50-60 santri. Guru membaca kitab yang diajarkan dihadapan seluruh santri, kemudian santri mendengar dan menulis sesuai dengan harakat (baris) dan terjemahan yang dibaca oleh guru tersebut. Guru membaca dan menterjemahkan kata-kata demi kata dengan menggunakan terjemahan harfiyah untuk memberikan kemudahan dan pemahaman kepada santri terjemahan dari teks yang dibaca. Kemudian guru menjelaskan maksud dari yang dibaca, sehingga sering karena keasyikan memberikan penjelasan, tidak disadari waktu telah berakhir. Namun, sebelum meninggalkan kelas, guru tetap memberikan kesempatan kepada santri untuk bertanya terkait dengan materi dan penjelasan yang disampaikan. Dalam penerapan metode ini, peran guru terlihat lebih aktif, sedangkan santri pasif karena hanya mendengar bacaan dan mencatat penjelasan yang disampaikan guru. 
3. Metode Halaqah. Pada dasarnya, dalam mengajarkan kitab kuning, para guru menerapkan metode ini dimana para santri duduk disekeliling guru dalam bentuk lingkaran. Bila dilihat dari segi bahasa, halaqah artinya lingkaran, orang-orang duduk melingkar. Karena pada awalnya proses belajar-mengajar diadakan di masjid dan di rumah guru. Dalam perkembangan selanjutnya, metode ini terus dipakai dalam kegiatan pengajian diluar jam belajar di lokal. Meskipun pada saat ini, pesantren Musthafawiyah telah menerapkan tingkatan kelas untuk santri, namun metode ini tetap dilaksanakan. Penerapan metode ini dilaksanakan di masjid dalam pengajian pagi dalam kegiatan belajar tambahan yang diadakan pada hari Sabtu-Senin mulai jam 06.30-07.15 WIB.

Adapun kitab yang diajarkan dalam kegiatan ini yaitu kitab yang tidak diajarkan dalam proses belajar-mengajar di lokal, seperti I'anatu at-Thalibin, al-Azdkar, Mukhtar al-Hadits, Nashaih al-'Tbad, dan $a r-R u d u d$. Selain itu, metode ini juga dilaksanakan dalam kegiatan pengajian pada waktu libur (bulan puasa). Namun, khusus pengajian pada bulan puasa ini hanya atas inisiatif dari santri yang diizinkan oleh pihak pesantren Musthafawiy- ah. Pengajian ini berlangsung selama satu bulan, yaitu dua minggu menjelang puasa dan dua minggu menjelang hari raya Idul Fitri.

4. Metode Hafalan. Proses pengajaran yang diterapkan di pesantren Musthafawiyah selain mengutamakan pemahaman terhadap kitab kuning, namun juga memaksimalkan tingkatan hafalan santri terhadap pelajaran yang sifatnya hafalan, seperti tafsir, juz 'amma, nahwu, saraf, dan hadits. Khusus, untuk nahwu dan saraf lebih ditekankan pada santri tingkatan dasar untuk menghafal Matan alJurumiyah (nahwu) dan Amtsilah alJadidah (saraf). Hal ini karena kedua kitab tersebut kitab dasar ilmu nahwu dan saraf, sehingga dengan menguasainya, baik dari segi hafalan maupun pemahaman akan lebih memudahkan santri untuk mengikuti tingkatan selanjutkan karena telah menguasai prinsipprinsip dasar ilmu nahwu dan saraf. Selain dari dua metode tersebut, metode hafalan menempati posisi yang penting di dunia pesantren. Dalam pelaksanaan metode ini, biasanya materi-materi tertentu diwajibkan untuk dihapal, seperti hadis, alquran. Hafalanhafalan tersebut biasanya berbentu nazam (syair), seperti kaidah-kaidah 
nahu seperti alfiyah (Daulay, 2012: 69).

\section{Pembahasan}

Mencermati tradisi, model pendidikan, dan metode pengajaran yang masih dipertahankan oleh pesantren Musthafawiyah merupakan suatu warisan yang dilanjutkan secara turun-temurun oleh generasi selanjutnya sebagai bentuk implementasi dari visi dan misi pesantren Musthafawiyah untuk memelihara tradisi keilmuan pesantren secara umum, maupun Musthafawiyah secara khusus. Karakteristik pesantren Musthafawiyah dari pesantren lain adalah kajian kitab kuning sebagai prioritas utama. Hal ini dapat dibuktikan dengan lambang kitab kuning yang ada di pesantren tersebut.

Sebagaimana dikemukakan oleh Azyumardi Azra, bahwa kitab kuning mengandung orisinalitas tertentu yang terdiri dari syarah dan hasyiyah, sehingga karya-karya keilmuan sekarang terlihat seolah-olah hanya mengulangi apa yang pernah ditulis oleh ulama-ulama terdahulu (Azra, 2002: 116). Menurut hemat penulis, pernyataan tersebut memang tepat dan dapat dibenarkan. Hal ini dikarenakan tidak semua kaum Muslimin, pelajar, maupun mahasiswa mampu membaca, memahami, dan mengambil makna dari teks kitab kuning, sehingga muncullah karya- karya terjemahan kitab kuning sebagai solusi alternatif bagi masyarakat dan pelajar Muslim yang ingin memahami masalah-masalah keislaman.

Kemajuan ilmu pengetahuan dan teknologi tidak mampu menggoyahkan pemikiran pihak pesantren untuk merubah dan mengganti tradisi tersebut. Seperti kitab kuning yang tetap menjadi kajian utama, meskipun banyak kitabkitab terjemahan yang muncul. Hal ini agar para santri mampu mengetahui dan memahami makna dari teks yang dibaca, disamping menambah wawasan kosa kata santri terhadap Bahasa Arab.

Selain itu, bila pengajaran kitab kuning yang selama ini berlangsung diganti dengan buku-buku terjemahan, maka ilmu-ilmu alat yang selama ini dipelajari hanya sebatas untuk menambah wawasan dan tidak akan dapat di implementasikan oleh santri, seperti ilmu nahwu (gramatika), saraf (morfologi), dan balaghah (stilistik). Hal ini dikarenakan, ketiga ilmu ini merupakan syarat mutlak untuk bisa membaca, memahami, dan mengambil maksud dari teks tersebut.

Begitu juga dengan model pendidikan yang tetap dipertahankan, seperti pemisahan ruang belajar santri dan santriwati (single sex education) merupakan tradisi yang masih bertahan hingga saat ini. Kebijakan 
dan konsep pemikiran struktural pesantren tentang hal ini sebagai tindakan preventif untuk memelihara sikap, tingkah laku, dan nilai-nilai yang luhur dalam diri seorang santri, sehingga terpelihara dari sikap tercela dan etika dalam bergaul dengan lawan jenis. Hal yang tidak berbeda jauh, juga bisa dilihat dari kebijakan yang lain, yaitu bahwa keberadaan guru-guru perempuan yang tidak diizinkan untuk mengajar santri lakilaki, namun guru laki-laki diizinkan untuk mengajar ke lokal santriwati. Tidak ada unsur diskriminatif terhadap kebijakan ini, melainkan hanya untuk melestarikan tradisi yang telah lama berlangsung, juga tidak ada pro-kontra dari guru-guru tersebut tentang kebijakan ini.

Selain itu, tidak semua guru lakilaki dizinkan mengajar ke lokal santriwati. Guru yang diizinkan hanyalah guru-guru senior yang mampu menjaga sikap, ucapan, dan tingkah lakunya kepada santriwati. Hanya guru yang memiliki jiwa kebapak-anlah yang diizinkan untuk mengajar santriwati tersebut. Jelasnya, kemampuan mengontrol diri dan emosional merupakan tolak-ukur seorang guru untuk mendapatkan izin mengajar para santriwati.

Namun, meskipun pesantren Musthafawiyah tetap mempertahankan tradisi dan model pendidikan yang selama ini berlangsung, bukan berarti struktural pesantren Musthafawiyah menutup diri terhadap kemajuan zaman dan ilmu pengetahuan. Ringkasnya, menurut hemat penulis, konsep pemikiran yang dipegang teguh oleh pesantren Musthafawiyah secara khusus yaitu "al-Muhafadzah 'ala al-Qadim as-Shalih wa al-Akhdz bi al-Jadid al-Aslah" (memelihara tradisi lama yang baik dan mengambil pembaruan yang lebih baik).

Sebagaimana yang diungkapkan oleh Ahmad Barizi bahwa falsafah tersebut merupakan nilai pokok yang melandasi kehidupan pesantren. Suatu falsafat yang cukup sederhana, namun mampu mentransformasikan potensi dan menjadikan pesantren sebagai agent of change sehingga mampu menjaga eksistensi pondok pesantren di tengah kemajuan ilmu pengetahuan dan teknologi, hingga terus dilirik dan diminati oleh masyarakat (Barizi, 2011: 46).

Maka tidak berlebihan bila penulis katakan bahwa istilah full day school yang akhir-akhir ini mengalami pro-kontra, diadopsi dari model pendidikan pesantren yang selama ini berlangsung, bahkan pesantren Musthafawiyah tidak hanya menerapkan full day school, melainkan "night school". Sebab, belajar-mengajar di pesantren Musthafawiyah di mulai dari pagi kira-kira pukul 06.30 hingga malam hari pukul 22.30 WIB. Jelaslah, 
bahwa bahwa santri tidak hanya diajar dan dididik, namun juga dibimbing, dan diawasi oleh guru yang berperan sebagai orang tua santri dalam hal pendidikan di lingkungan pesantren Musthafawiyah.

\section{PENUTUP}

\section{Kesimpulan}

Eksistensi pesantren Musthafawiyah sampai saat ini dikarenakan kemauan dan kemampuan pesantren untuk mempertahankan tradisi yang telah lama dibina oleh pendiri pertama, terutama kajian kitab kuning yang ditopang dengan biaya pendidikan dan biaya hidup yang relatif murah sehingga dapat dijangkau oleh santri yang berasal dari tingkatan ekonomi yang berbeda. Karena tidak ada jaminan bahwa biaya pendidikan yang murah menunjukkan kualitas pendidikannya rendah, begitu juga sebaliknya.

Pesantren Musthafawiyah masih mempertahankan tradisi dan model pendidikan yang selama berlangsung dikarenakan keinginan struktural pesantren Musthafawiyah untuk melanjutkan tradisi yang telah dibina oleh syekh Musthafa Husein dan juga konstruk pemikiran struktural terhadap relevansi model pendidikan pesantren Musthafawiyah di tengah modernisasi pendidikan. Bahkan konstruk pemikiran struktural pesantren Musthhafawiyah relevan dengan model pendidikan moderen yang menuntun terhadap kreatifitas santri melalui metode sorogan yang lazim diterapkan di pesantren. Tidak berlebihan bila dikatakan bahwa kitab kuning sebagai sarana yang tepat untuk menerapkan strategi dan metode student center, seperti metode diskusi dengan model inkuiri.

\section{Saran}

Pelaksanaan proses pengajaran kitab kuning dengan menggunakan motode sorogan mesti ditekankan untuk meningkatkan daya pikir dan kritis santri dalam memahami kitab kuning. Sebab, dengan metode ini seorang guru bisa mengetahui tingkat pengetahuan dan pemahaman santri terhadap ilmu alat yaitu ilmu nahwu (gramatika), saraf (morfologi), dan balagah (stilistik). Hal ini karena metode sorogan sangat efektif dalam mengajarkan kitab kuning, meskipun tidak efesien.

Orientasi keilmuan pesantren Musthafawiyah yang selama ini fokus terhadap penguasan kitab kuning perlu ditambah dengan kemampuan berbahasa asing. Sehingga para alumni ponpes Musthafawiyah mampu menguasai kitab kuning dan berbahasa asing. Sebab, kemajuan zaman dan ilmu pengetahuan menuntut pesantren mesti berbenah 
dan beradaptasi dengan kemajuan zaman dan ilmu pengetahuan tanpa harus menghilangkan identitas dan elemen pesantren itu sendiri. Maka struktural pesantren harus mampu mengoptimalkan fasilitas yang ada untuk meningkatkan kualitas santri/santriwati dalam mengadapi tantangan zaman.

\section{KEPUSTAKAAN ACUAN}

Arief, Armai, Cet. 1. 2002. Pengantar Ilmu dan Metodologi Pendidikan Islam. Jakarta: Ciputat Pers.

Assegaf, Abdurrahman. 2013. Aliran Pemikiran Pendidikan Islam. Jakarta: Rajawali Pers.

Azra, Azyumardi 2012. Pendidikan Islam; Tradisi dan Modernisasi di Tengah Tantangan Milenium Baru. Jakarta: Kencana.

Barizi, Ahmad. 2011. Pendidikan Integratif; Akar Tradisi dan Keilmuan Pendidikan Islam. Malang: UIN Maliki Press.

Depdikbud. Ed. 2. 1994. Kamus Besar Bahasa Indonesia. Jakarta: Balai Pustaka.

Mastuhu. Cet.1. 1994. Dinamika Sitem Pendidikan Pesantren. Jakarta: INIS.

Daulay, Putra Haidar. 2009. Sejarah Pertumbuhan dan Pembaruan
Pendidikan Islam di Indonesia. Jakarta: Kencana.

Salim, Peter dan Yenny Salim, Ed.1. 1991. Kamus Besar Bahasa Indonesia Kontemporer. Jakarta: Modern English Press.

Tatang. (2012). Ilmu Pendidikan. Bandung: Pustaka Setia.

Utomo, Wahyu. Cet.1. 1997. Perguruan Tinggi Pesantren Pendidikan Alternatif Masa Depan. Jakarta: Gema Insani Press.

Zuhairini,dkk. Cet.8. 1983. Metode Khusus Pendidikan Agama. Surabaya: Usaha Nasional.

Bina Pesantren. Ed. 2. (2006). Media Informasi dan Artikulasi Dunia Pesantren. Jakarta Selatan.

Taruna, Mudis Mulyani. (2013). Manajemen Pendidikan Ma'had 'Aly di Lingkungan Pondok Pesantren: Kasus Ma'had 'Aly Hasyim Asy'ari Tebuireng, Jombang. Edukasi: Jurnal Penelitian Agama dan Keagamaan, 11 (2).

Ngatawi, El-Zastow. (2006). Dialog Pesantren Barat: Transformasi Dunia Pesantren. Jakarta: Departemen Pendidikan Diniyah dan Pondok Pesantren. Jurnal Pondok Pesantren: Mihrab Komunikatif Dalam Berwacana, 1 (IV). 
Susanne, Kreitz-Sandberg. (2013).

Sweden: Department of

Gender Inclusion and Horizontal Behavioural Science and Gender Segregation: Stakeholders' Learning, Linköping University, Strategies and Dilemmas in Swedish Teachers' Education. Linköping. 